\title{
NILAI KESEMPURNAAN KRISTEN DALAM KITAB IBRANI
}

\author{
Oleh : Seri Damarwanti ${ }^{1}$
}

\begin{abstract}
Christian perfection is not just an expression that contains expectations for Christians, but rather a standard of living that is commanded and required for every Christian. The book of Hebrews teaches that the values of Christian Perfection are closely related to holiness, with Perfection being the nature of God and the result of his work.

Christian perfection is perfection that originates from Holiness of life, of love and of motivation, from and understanding and recognition that Christ's saving work completely resolves the problem of sin, and is valid for ever. Perfection is seen and birthedin the figure of Jesus Christ our High Priestas well as the perfect sin offering, who completed his work of attonement in the more perfect heavenly Tablernacl, not made by human hands.Christian perfection is inseparable from the meaning of Holiness, demanded of all Christians.
\end{abstract}

Keywords: Christian perfection, Hebrew, holiness, love, motivation

\section{Pendahuluan}

Manusia diciptakan sesuai dengan gambar dan citra Allah. Dalam pemahaman iman Kristen, orang percaya memiliki "model" dalam berpikir, berperasaan, berkata-kata dan bersikap, dimana model itu adalah Tuhan Yesus Kristus, yang merupakan pribadi perwujudan dari Allah Bapa, Tuhan Yang Maha Kuasa. Karena manusia diciptakan segambar dan serupa dengan Allah, maka manusia perlu hidup sesuai dengan standar-standar yang ditetapkan Allah.Standar kehidupan itu ada di dalam FirmanNya.Sebagaimana Yesus Kristus memiliki nilai-nilai yang menjadi standar untuk dijalani, sedemikian itu pulalah murid-muridNya hidup dalam standar yang sama dengan Dia.

Standar yang paling utama dalam kehidupan Kristen, salah ada dalam Matius 5:8, dimana Yesus berkata :"Hendaklah kamu sempurna sama seperti Bapamu yang di sorga adalah sempurna". Artinya, Allah Bapa, adalah Allah yang sempurna dalam kepribadianNya, dalam apa yang dikerjakanNya dan dalam apa yang dihasilkanNya dari semua karyaNya. Ia sempurna dalam Kasih, dalam motivasi, dalam keseluruhan hidupNya.

\footnotetext{
${ }^{1}$ S eri Damarwanti adalah aktivis di Gereja Kristen Nazarene Filadelfia Yogyakarta dalam pelayanan kaum wanita, anak serta liturgi dan ibadah. Penulis mangajar di Sekolah Tinggi Theologia Nazarene indonesia dan sekaligus menjadi Wakil Ketua I Bidang Akademik. Mendapat gelar Sarjana Ekonomi (S.E.) di Universitas Pembangunan Nasional Veteran Yogyakarta, dan menyelesaikan program Magister Teologi (M.Th) di STTNI Yogyakarta dan sekarang sedang menempuh program Doktoral di STTII Yogyakarta.
} 
Kesempurnaan merupakan bagian dari kepribadianNya.Ia menuntut umatNya, sama sempurna seperti Dia.

Tentu saja bukan kesempurnaan tanpa cacat yang dimaksudkan di sini."Kesempurnaan Kristen" tidaklah berarti bahwa manusia dapat menjadi sempurna seperti Allah atau benarbenar lepas dari kesalahan moral. John Wesley, seorang pendiri Gereja Methodist berpendapat bahwa perlu tetap menyadari keterbatasan manusia dan bahwa hanya Allah yang memiliki kesempurnaan absolut dan percaya bahwa kesempurnaan manusia baru datang dalam kehidupan mendatang di dalam Kristus. Ia juga percaya bahwa pemulihan Kristus dimulai sejak manusia menjalani kehidupannya yang terbatas dan kesempurnaan juga dimulai pada kehidupan ini. Sebenarnya apa yang Wesley maksudkan dengan doktrin ini adalah kesempurnaan dalam kasih, yaitu bagaimana menjadi seseorang yang sungguh-sungguh dipenuhi kasih yang tidak lagi diperbudak oleh kepentingan diri, melainkan senantiasa mengasihi Allah dan sesama. ${ }^{2}$

Dalam Kitab Ibrani, terdapat juga beberapa prinsip mengenai kesempurnaan Kristen. Penulis berpendapat bahwa ada hubungan yang erat antara Kesempurnaan dan Kekudusan hidup orang percaya, sehingga ada beberapa bagian dalam ayat-ayat di bawah ini akan mengupas mengenai keeratan hubungan itu.

\section{Latar Belakang Kitab Ibrani}

\section{Waktu Penulisan}

Tidak ada rujukan yang pasti mengenai waktu penulisan surat ini. Kesepakatan yangumum diterima adalah surat Ibrani ditulis sebelum tahun 100 Masehi. ${ }^{3}$ Robinson menyakini surat ini ditulis pada tahun $67 \mathrm{M} .{ }^{4}$ Pendapat lain memberi perkiraan tahun 8196, ${ }^{5}$ atau tahun $93-96 .^{6}$

\section{Penulis Kitab Ibrani}

Penulis surat ini tidak mencantumkan namanya, sehingga tidak diketahui pasti. Pada abad-abad pertama kekristenan hingga Abad Pertengahan, surat Ibrani diyakini ditulis oleh

\footnotetext{
${ }^{2}$ Waldo Beach, H. Richard Niehbuhr, Christian Ethics: Sources of the Living Tradition (New York: The Ronald Press Company, 1955), 359-360

${ }^{3}$ Bambang Subandrijo, Menyingkap Pesan-pesan Perjanjian Baru 2 (Bandung: Bina Media Informasi, 2010), 15.

${ }^{4}$ John Arthur Thomas Robinson (1919-1983), Redating the New Testament, (Westminster Press, , 1976), 369.

${ }^{5}$ A. Harnack, Geschichte der altchristlichen Litteratur bis Eusehius, Vol II, 1893,7.

${ }^{6}$ W. G. Kummel, Introduction to the New Testament, Heidelberg, 1963, 219
} 
Rasul Paulus, meskipun tidak dimulai dengan nama Paulus, seperti surat-surat Paulus lainnya. ${ }^{7}$ Pandangan ini kehilangan banyak pendukungnya, karena beberapa hal, yaitu :

Pertama, Gaya penulisan surat ini berbeda dengan gaya penulisan Rasul Paulus. ${ }^{8}$ Kedua, ada keterangan di dalam surat ini yang menyebutkan bahwa si penulis adalah orang yang menerima perkataan Kristus dari orang lain (Ibrani 2:3), sementara Paulus sendiri mengaku sebagai saksi mata yang telah melihat Yesus dan dengan demikian memiliki status yang sama dengan rasul-rasul yang lain. ${ }^{9}$ Barnabas dan Apolos juga disebut-sebut sebagai penulis surat ini, namun pandangan ini tidak didukung cukup bukti. Akhirnya, para pakar modern sepakat bahwa tidak ada kepastian mengenai penulis surat ini. ${ }^{10}$ Yang jelas, penulisnya adalah orang berpendidikan yang terlatih dalam hukum Taurat, retorika Yunani yang juga mengenal dengan baik filsafat Plato. ${ }^{11}$

\section{Tujuan Penulisan Kitab Ibrani}

Kitab Ibrani ditulis untuk orang-orang Kristen yang menghadapi permulaan penganiayaan yang hebat dan dicobai untuk mencari perlindungan dibawah naungan iman Yahudi mereka sebelumnya. Pokok pembahasan ini adalah mengenai keutamaan Kristen jika dibandingkan dengan jalan keselamatan dalam Perjanjian Lama. Tujuan penulisan kitab ini adalah mendorong orang-orang percaya untuk maju terus, dan bukannya mundur. Kitab ini terutama menakankan pada kepenuhan penyediaan berkat Kristus untuk menghapuskan polusi dan kuasa dosa yang bertentangan dengan keterbatasan korban -korban binatang dalam bait Allah Yahudi.

Salah satu sumbangan dalam Kitab Ibrani adalah hubungan yang erat antara KESEMPURNAAN dengan PENGUDUSAN. Oscar Cullman berpendapat bahwa penulis berusaha untuk membuat kedua hal itu sinonim. ${ }^{12}$ Ada satu perasaan yang kuat tentang keharusan dimilikinya kesucian, satu tuntutan mendesak dalam membuat pilihan antara “ beralih kepada perkembangannya yang penuh" (maju terus sampai pada kesempurnaan) atau "mengundurkan diri dan binasa". 13

\footnotetext{
${ }^{7}$ Willi Marxsen, Pengantar Perjanjian Baru: Pendekatan Kristis terhadap Masalah-masalahnya (Jakarta: BPK Gunung Mulia), 2005, 266.

${ }^{8}$ Dianne Bergant \& Robert J. Karris (eds), Tafsir Alkitab Perjanjian Baru (Yogyakarta: Kanisius), 2002 413.

${ }^{9}$ Subandrio, Menyingkap Pesan-pesan Perjanjian Baru 2, 15.

${ }^{10}$ Ibid, 15.

${ }^{11}$ John Drane, Memahami Perjanjian Baru: Pengantar Historis - Teologis (Jakarta: BPK Gunung Mulia, 2001), 476-477.

${ }^{12}$ Oscar Cullman, The Christology of the New Testament, pen., Shirley G Guthrie dan Charles A.M (Philadelphia: Westmister Press, 1963), 100.

${ }^{13}$ W.T Purkisser, Menggali Kekudusan Kristen, Jilid 1 (Yogyakarta: Andi Offset, 1988), 250.
} 


\section{Tentang Kesempumaan Kristen}

Di dalam Perjanjian Lama, Kesempurnaan Allah antara lain ditunjukkan dalam hal pekerjaan-Nya, segala jalan-Nya yang adil, kesetiaan-Nya, dengan tiada kecurangan, Ulangan 32:4, sabda-Nya yang murni, perlindungan-Nya, Ulangan 22:31, Mazmur 18:31, pengetahuan-Nya, Ayub 36:2-4. Taurat-Nya yang menyegarkan jiwa, perkataan-Nya yang teguh, memberikan hikmat kepada orang yang tak berpengalaman, Mazmur 19:8, hukumNya yang memerdekakan (eleutheria, kebebasan) orang.

Di dalam Perjanjian Baru, kata sempurna (teleios dalam bahasa Yunani), bisa berarti sudah mencapai tujuan, lengkap, utuh, genap, dewasa, matang. Ketika pelayanan di dunia pun Tuhan Yesus telah melakukan penggenapan (sunteleo, menyelesaikan, mengakhiri; meletakkan, membuat [perjanjian]; melaksanakan, mewujudkan) firman Allah dengan sempurna, Roma 9:28. Menurut Yakobus 3:2, siapa yang tidak pernah bersalah (ptaio, tersandung, berdosa) karena tidak pernah tersandung dalam perkataannya, ia adalah orang yang sempurna (teleios, sudah mencapai tujuan, lengkap, utuh, genap; dewasa), sebab ia dapat mengendalikan dan mengekang semua anggota tubuhnya.

\section{Nilai Kesempumaan Kristen Dalamkitab Ibrani}

\section{Ibrani 2:10-11 - Kita Ambil Bagian Dalam KesempurnaanNya}

"Sebab memang sesuai dengan kehendak Allah - yang bagiNya dan olehNya segala sesuatu dijadikan, yaitu Allah yang membawa banyak orang kepada kemuliaan, juga menyempumakan Yesus, yang meminpin mereka kepada keselamatan, dengan penderitaan. Sebab ia yang menguduskan (hagiazo) dan mereka yang dikuduskan, mereka semua berasal dari Satu ; itulah sebabnya Ia tidak malu menyebut mereka saudara"

Dalam versi NIV :(ayat 10) . . . to make the captain of their salvation perfect through sufferings.

Bagian ini perlu diperhatikan karena bagian ini memberikan penjelasan yang meneguhkan identitas kwalitatif dari orang yang menguduskan dan yang dikuduskan, berasal dari Satu. H Norton Wileey menuliskan : “ jadi sangat jelas bahwa Ia yang membawa banyak orang kepada kemuliaan, melakukan hal itu dengan menguduskan mereka, dan kekudusan merupakan satu-satunya jalan untuk menuju kemuliaan bagi anak-anak Allah". ${ }^{14}$ Ditambahkan lagi, F.F Bruce memberikan komentar : "Pengudusan merupakan permulaan dari kemuliaan, dan kemuliaan adalah penyempurnaan dari pengudusan", 15

\footnotetext{
${ }^{14}$ H. Orton Willey, The Epistle of the Hebrew (Kansas City, Beacon Hill Press,1959), 90.

${ }^{15}$ F.F Bruce, The Epistle of the Hebrews, NICNT (Grand Rapids: William B Eerdsmans Publishing Co,
} 1964), 45. 
Kata hagios atau suci berarti bukan hanya tindakan pemurnian atau penyucian, tetapi juga kehadiran Kristus yang tinggal tetap dalam baitNya yang telah disucikan ; dan kehadiranNya di dalam kita itulah yang menguduskan dan membuat kita menjadi milikNya. Keserupaan dengan Allah melalui pengudusan ini merupakan arti yang lebih dalam tentang apa maknanya menjadi anak-anak Allah dalam Perjanjian Baru.

Mengacu pada Yohanes 15 mengenai Pokok Anggur yang benar, Yesus adalah Pokok Anggur dan orang Kristen adalah ranting-rantingnya.Ranting menempel dan bergantung hidup, memperoleh kehidupan dari pokok anggur. Keduanya mendapatkan kehidupan dari sumber yang sama. Apa yang didapat dan terjadi pada ranting, tidak lepas dari apa yang diberikan dan diterima dari Pokok Anggur. Ranting adalah bagian yang tidak terpisahkan dari pokok anggur dan mendapatkan kehidupan darinya. Sehingga sebagaimana pokok anggur, demikian pulalah rantingnya, sepanjang ranting selalu menempelkan dirinya pada Pokok dan mendapatkan sumber makanan yang sama.

Ambil bagian dan menjad serupa dalam kesempurnaan Allah merupakan implikasi yang tidak dapat dihindari orang Kristen dari kehidupan yang kudus, yang sesuai dengan kesempurnaanNya.

\section{Ibrani 6 : 1-3 - Pemahaman Yang Semakin Sempurna Kepada Kristus}

“ Sebab itu marilah kita tinggalkan azas-azas pertama dari ajaran tentang Kristus dan beralih pada perkembangannya yang penuh (teleioteta). Janganlah kita meletakkan lagi dasar pertobatan dari perbuatan-perbuatan yang sia-sia, dan dasar kepercayaan kepada Allah. Yaitu ajaran tentang berbagai pembaptisan, penumpangan tangan, kebangkitan orang-orang mati dan hukuman kekal. Dan itulah yang akan kita perbuat, jika Allah mengijinkannya.

Dalam NIV :"Therefore, leaving the discussion of the elementary principles of Christ, let us go on to perfection, not laying again ... .

Bagian ini merupakan salah satu teks tentang kesempurnaan yang sangat menonjol. Persisnya arti "perkembangan yang penuh" di sini tidak perlu diperdebatkan, namun cukup wajar untuk menunjukkan bahwa teleios (akar kata teleioteta) yang dipakai di sini berarti "komplit", menggambarkan ide tentang kebaikan teta sendiri, yang diterjemahkan menjadi "mempersatukan dan menyempurnakan", seperti yang tertulis dalam Kolose 3:14, satusatunya teks dalam Perjanjian Baru yang memuat istilah tersebut. Teleios tidak hanya dipakai dalam pengertian dewasa dalam Perjanjian Baru, tetapi juga dipakai dalam konteks dimana "dewasa" tidak cocok, contohnya mengenai Allah sendiri (Matius 5:48), Kristus (Ibrani 5:9), karya penebusan Kristus (Lukas 13:32), "hukum yang memerdekakan" (Yakobus 1:25), kemah surgawi ( Ibrani 9:11) dan kehendak Allah (Roma 12:2). ${ }^{16}$

Jadi, menjadi Kristen tidak sekedar puas dengan dasar-dasar Iman dan beretorika mengenainya saja, namun lebih dari itu, menjadi Kristen memerlukan tahap perkembangan

\footnotetext{
${ }^{16}$ Purkisser, Menggali Kekudusan Kristen, 256.
} 
selanjutnya. Seperti bayi rohani yang selalu membutuhkan air susu yang rohani, dasar-dasar Iman Kristen menjadi syarat mutlak dalam mengenal Prinsip Dasar Kekristenan, sama seperti air susu rohani yang murni. Namun prosesnya tidak berhenti sampai di sini saja. Orang Kristen perlu mengenai apa yang dipercayainya dengan lebih baik. pengenalannya akan kebenaran Firman Tuhan dan pribadi Allah dalam Yesus Kristus juga harus semakin baik. Mencapai pemahaman yang utuh dan menyeluruh, sempurna kepada Tuhan Yesus Kristus.

\section{Ibrani 7:25 - Karya PenyelematanNya Sempurna}

'Karena itu Ia sanggup menyelamatkan dengan sempuma semua orang yang oleh Dia datang kepada Allah. Sebab Ia hidup senantiasa untuk menjadi pengantara mereka".Dalam NIV :"Therefore He is also able to save to the uttermost those who came to God through Him, since He always lives to make intercession for them ".

"Dengan sempurna" diterjemahkan darieis to panteles, suatu istilah yang artinya lebih mengarah kepada kesempurnaan daripada jangka waktu (Lukas 13:11). Berarti bahwa, Ia dapat menyelamatkan sepenuhnya dan dengan sempurna orang-orang yang mendekati Allah melalui Dia. Amplified Bible menggabungkan ide tentang kesempurnaan dan jangka waktu : "secara tuntas, dengan sempurna, sampai pada akhirnya dan untuk selama-lamanya dan kekal". 17

Karya pengorbanan Kristus di kayu salib dalam menebus dosa manusia adalah tuntas, selesai, tak meninggalkan bayangan dan masalah baru, sempurna.Tidak perlu diragukan.Karya penebusannya layak dipercaya secara penuh sudah tuntas menyelesaikan masalah dosa yang dihadapi manusia, termasuk konsekwensi - konsekwensi dosa tersebut.Semua lunas dibayar, lunas ditebus oleh penumpahan Yesus Kristus di kayu salib.

Ibrani 7:28 \& Ibrani 11:40 -- Imam Besar Yang Sempurna

"Sebab hukum Taurat menetapkan orang-orang yang diliputi kelemahan menjadi Imam Besar, tetapi sumpah, yang diucapkan kemudian daripada Hukum Taurat menetapkan Anak, yang telah menjadi sempurna sampai selama-lamanya . . . Sebab Allah telah menyediakan sesuatu yang lebih baik bagi kita, tanpa kita mereka tidak dapat sampai kepada kesempurnaan". Dalam NIV :"For the appoints as high priest men who have weakness, but the word of the oath, which came after the law, appoints the Son who has been perfected forever . . . God having provided something better for us, that they should not be made perfect apart from us"

\footnotetext{
${ }^{17}$ Bruce, The Epistle of the Hebrews, 114.
} 
Dalam Ibrani 7:28, Allah menetapkan (kathistemi, mendudukkan; mengangkat; mengiringi; menjadikan diri; menetapkan sebagai pimpinan) bahwa Yesus yang telah dijanjikan itu sempurna sampai selama-lamanya. Yesus telah dibawa pada suatu tujuan untuk diperlengkapi, disempurnakan melalui inkarnasi kehidupan insani, sehingga kematian dan kebangkitan-Nya menjadikan Dia layak untuk menjadi Imam Besar.Sebab (peri, bagi, tentang, mengenai, untuk; karena) Allah telah menyediakan (problepomai, menentukan sebelumnya, nampak lebih dahulu) sesuatu yang lebih baik (kreitton, lebih kuat, lebih tinggi, lebih unggul, lebih terhormat dan mulia, lebih besar) bagi kita; tanpa kita, mereka tidak dapat sampai kepada kesempurnaan, Ibrani 11:40.

\section{Ibrani 9:11 - Kemah Yang Lebih Sempurna}

"Tetapi Kristus telah datang sebagai Imam Besar untuk hal-hal yang baik yang akan datang ; Ia telah melintasi kemah yang lebih besar dan yang lebih sempurna, yang bukan dibuat oleh tangan manusia, - artinya yang tidak termasuk ciptaan ini,-.Dalam NIV :BBut Christ came as High Priest of the good things to come, with the greater and more perfect tabernacle not made with hands. that is, not of this creation.

Menurut Ibrani 9:11, sebagai Imam Besar untuk hal-hal yang baik yang akan datang (mello, sebentar lagi akan; hendak; harus), Kristus telah melintasi kemah yang lebih besar dan lebih sempurna, yang tidak termasuk ciptaan (ktisis, makhluk; dunia; penciptaan) atau dunia ini.

Imam Besar dan Tabernakel lahiriah di padang gurun hanyalah merupakan "suatu gambaran" dari "apa yang sebenarnya", yang lebih mulia, yang lebih sejati dari kemah kediaman orang Kristen di surge kelak. Gambaran lahiriah itu berbicara mengenai symbol yang memiliki makna.Namun bukan pada symbol lahiriah itu letak iman kita, namun pada Iman dan kasih dalam perbuatan. "Kemah Surgawi" dan "Imam Besar Yesus Kristus"merupakan perwujudan yang sempurna dari symbol lahiriah yang ada di padang gurun.

\section{Ibrani 10:14-Yesus Kristus Korban Yang Sempurna}

"Sebab oleh satu korban saja Ia telah menyempurnakan untuk selama-lamanya mereka yang Ia kuduskan".Dalam NIV : "For bu one offering, He has perfected forever those who are being sanctified"

"Dikuduskan atau kuduskan" dalam teks itu berasal dari kata hagiazo, dipakai untuk perfect ; ini menunjukkan bahwa keadaan itu telah selesai dan hasilnya sampai saat ini masih dirasakan. Sedangkan dalam LAI dipakai sebagai untuk mencerminkan tindakan yang masih berlangsung, dan menurut Hewitt merupakan "kata yang diulang-ulang" yang berarti bahwa 
"orang yang dari waktu ke waktu menerima pengudusan". ${ }^{18}$ Oscar Cullman tertarik akan hubungan yang erat antara kesempurnaan dan kekudusan. Dalam ayat 14 ia menulis :

Seperti halnya konsep iman besar yang diterpkan oleh Yesus telah digenapi sehingga konsep tata cara ibadah yang murni secara umum telah ditinggikan ke tingkat yang lebih tinggi , maka konsep tata cara ibadah yang murni teleioun (membuat sempurna) yang diterapkan padaNya juga harus melibatkan pengertian tentang menjadikan sempurna dalam bidang moral. Hal ini sungguh-sungguh terjadi dalam kehidupan manusia dalam Yesus, Imam Besar, yang dijadikan sempurna, yang dikuduskan, yang dijadikan sempurna olehNya (Ibrani 2:11) ${ }^{19}$.

Ia menambahkan, "sebab oleh pengorbanan satu kali telah menyempurnakan untuk selama-lamanya orang-orang yang dikuduskan (Ibrani 10:14). Teleioun (menjadikan sempurna) mendekati sinonim dari hagiazein (menguduskan). Jadi Ibrani 2:11 maksudnya, “ sebab Ia yang menguduskan dan mereka yang dikuduskan, semua berasal dari satu sumber' ${ }^{20}$

Dalam Perjanjian Lama, korban hewan merupakan gambaran dari korban yang sejati untuk keselamatan manusia. Pilihan terhadap hewan yang tidak bercacat mengacu pada Manusia Yesus Kristus sebagai korban bagi penebusan dosa yang tidak berdosa.Manusia lahiriah yang suci.Penumpahan darah korban sebagai tanda legalitas untuk penebusan dosa terwujud sempurna dengan penumpahan darah Kristus melalui penyalibanNya. Yesus Kristus merupakan penggenapan yang sempurna akan penebusan dosa umat manusia. Ia juga menyelesaikan masalah dosa dengan sempurna, tanpa menyisakan bayangan ketidakberesan akan apa yang telah dikerjakannya dalam penebusan orang berdosa.

\section{Kesimpulan dan Penutup}

Sekali lagi, Kesempurnaan Kristen bukanlah merupakan menjadi seperti Allah yang sempurna dan dapat lepas dari kesalahan moral. Ini merupakan hal yang mungkin untuk dilakukan oleh pengikut Kristus, mengingat "menjadi sempurna" adalah sebuah perintah ketika FirmanNya mengatakan : "Hendaklah kamu sempurna sama seperti Bapamu yang di sorga adalah sempurna". Artinya, Allah Bapa, adalah Allah yang sempurna dalam kepribadianNya, dalam apa yang dikerjakanNya dan dalam apa yang dihasilkanNya dari semua karyaNya. Ia sempurna dalam Kasih, dalam motivasi, dalam keseluruhan hidupNya. Kesempurnaan merupakan bagian dari kepribadianNya.Ia menuntut umatNya, sama sempurna seperti Dia.

Dan kesempurnaan erat hubungannya dengan Kekudusan.Kekudusan dan Kesempurnaan merupakan dua hal yang saling bersyarat dan mempengaruhi.'Pengudusan

\footnotetext{
${ }^{18}$ Ibid, 159.

${ }^{19}$ Cullman, The Christology of the New Testament, 93

${ }^{20}$ Ibid, 100.
} 
merupakan permulaan dari kemuliaan, dan kemuliaan adalah penyempurnaan dari pengudusan".Sebagai pengikut Yesus Kristus, orang Kristen harus menjadikan Kesempurnaan Kristen sebbagai orientasi yang paling utama dalam kehidupan, melalui Pengudusan hidup yang menyeluruh. Benarlah apa yang tertulis : tanpa kekudusan, tidak seorangpun akan melihat Allah. 


\section{DAFTAR PUSTAKA}

Arthur, John dan Thomas Robinson (1919-1983). Redating the New Testament. Westminster Press. 1976

Beach, Waldo dan H. Richard Niehbuhr. Christian Ethics: Sources of the Living Tradition. New York: The Ronald Press Company, 1955

Bergant, Dianne \& Robert J. Karris (eds). Tafsir Alkitab Perjanjian Baru. Yogyakarta: Kanisius, 2002

Bruce, F.F. The Epistle of the Hebrews. NICNT, Grand Rapids: William B Eerdsmans Publishing,Co, 1964

Cullman, Oscar. The Christology of the New Testament, diterjemahkan oleh Shirley G Guthrie and Charles A.M, (edisi revisi) Philadelphia: Westmister Press, 1963

Drane, John. Memahami Perjanjian Baru: Pengantar Historis - Teologis. Jakarta: BPK Gunung Mulia, 2001

Harnack, A. Geschichte der altchristlichen Litteratur bis Eusehius, Vol II, 1893

Kummel, W. G. Introduction to the New Testament. Heidelberg, 1963

Marxsen,Willy. Pengantar Perjanjian Baru: Pendekatan Kristis terhadap Masalahmasalahnya. Jakarta: BPK Gunung Mulia, 2005

Putkisser, W.T. Menggali Kekudusan Kristen Jilid 1, Yogyakarta, Andi Offset, 1988

Subandrio, Bambang. Menyingkap Pesan-pesan Perjanjian Baru 2. Bandung: Bina Media Informasi), 2010

Willey, H. Orton. The Epistle of the Hebrew. Kansas City: Beacon Hill Press, 1959. 